\title{
Historical records of orchid bees (Apidae: Euglossini) in Belém Endemism Center: species list of 92 years sampling
}

\author{
T. F. Brito ${ }^{a *}$, A. C. S. Santos ${ }^{b}$, M. M. Maués ${ }^{b}$, O. T. Silveira ${ }^{c}$ and M. L. Oliveira ${ }^{d}$ \\ ${ }^{a}$ Laboratório de Biologia e Ecologia de Abelhas, Programa de Pós-graduação em Zoologia, Museu Paraense Emílio \\ Goeldi - MPEG, Instituto de Ciências Biológicas, Universidade Federal do Pará - UFPA, Av. Perimetral, 2224, Guamá, \\ CEP 66075-110, Belém, PA, Brasil \\ bLaboratório de Entomologia, Embrapa Amazônia Oriental, Empresa Brasileira de Pesquisa Agropecuária - EMBRAPA, \\ Trav. Doutor Enéas Pinheiro, s/n, Marco, CEP 66095-903, Belém, PA, Brasil \\ 'Coleção de Invertebrados, Coordenação de Zoologia, Museu Paraense Emilio Goeldi - MPEG, Av. Perimetral, 1901/1907, \\ Campus de Pesquisa, Terra Firme, CEP 66017-970, Belém, PA, Brasil \\ ${ }^{\mathrm{d}}$ Coordenação de Biodiversidade, Instituto Nacional de Pesquisas da Amazônia - INPA, \\ Av. André Araújo, n 2936, Petrópolis, CEP 69067-375, Manaus, AM, Brasil \\ *e-mail: thalinebrito@gmail.com
}

Received: May 17, 2017 - Accepted: October 17, 2017 - Distributed: May 31, 2019 (With 3 figures)

\begin{abstract}
The distribution of most species occurs in delimited regions with unique characteristics called "centers of endemism". In Eastern Amazon is located the Belém Endemism Center (BEC), one of the most intensely deforested in Brazilian Amazon. Here, we show information about orchid bee assemblages based on historical records from entomological collections. For each species, we calculated occurrence frequency and dominance, and we classified them in 3 statuses: common, intermediate or rare species. Curves of observed and estimated richness were built, based on Jackknife estimator. We found 1,257 specimens from 56 species, constituting records from 1917 to 2009, and one species is a new record for BEC. Higher number of specimens and species was concentrated in a few locations and surveys increased from the 70's. The results suggest a high richness of orchid bees in the BEC, although this scenario is far from what is expected for the entire area. The high occurrence of rare species may be related to their low representativeness in the collections, and the proximity between the areas had favored samplings. Even so, the species list and the conservation status presented here may be useful information in studies comparing past and current orchid bee fauna, and, allied to data on bees' responses to land use changes occurred in BEC over the years, can fit as a basis for defining priority areas for conservation.
\end{abstract}

Keywords: Amazon, scent baits, collections, Brazil, deforestation.

\section{Registros históricos de abelhas-das-orquídeas (Apidae: Euglossini) no Centro de Endemismo Belém: lista de espécies de 92 anos de amostragens}

\section{Resumo}

A distribuição da maioria das espécies ocorre em regiões delimitadas com características únicas conhecidas como "centros de endemismo". Na Amazônia Oriental está localizado o Centro de Endemismo Belém (CEB), uma das áreas mais intensivamente desmatadas na Amazônia Brasileira. Aqui, apresentamos informações sobre assembleias de abelhas orquídeas baseadas em registros históricos de coleções entomológicas. Para cada espécie, foram calculadas a frequência de ocorrência e a dominância, classificando-as em 3 estados: espécies comuns, intermediárias ou raras. Foram geradas curvas de riqueza observada e estimada, com base no estimador Jackknife. Encontramos 1.257 espécimes de 56 espécies, constituindo registros de 1917 a 2009, e uma espécie é um novo registro no CEB. Maior número de espécimes e espécies foi concentrado em poucos locais, com intensificação nas coletas a partir dos anos70. Os resultados sugerem alta riqueza de abelhas orquídeas no CEB, embora esse cenário esteja longe do que é esperado para toda a área. A elevada ocorrência de espécies raras pode estar relacionada à baixa representatividade nas coleções e a proximidade entre as áreas favoreceu as amostragens. Mesmo assim, a lista de espécies e o estado de conservação aqui apresentados podem ser informações úteis em estudos interessados em comparar a fauna passada e atual de abelhas das orquídeas e, aliado a dados sobre as respostas das abelhas às mudanças de uso da terra ocorridas no CEB ao longo dos anos, podem servir de base para definição de áreas prioritárias para conservação.

Palavras-chave: Amazônia, armadilhas odoríferas, coleções, Brasil, desmatamento. 


\section{Introduction}

Amazonia is the most diverse ecosystem forming a mosaic of animal and plant communities. Most species are not widely distributed across this ecosystem but occur in clearly delimited areas, separated by the major rivers, each with their own evolutionary relationships and biotic assemblages, called "centers of endemism" (Cracraft and Prum, 1988; Haffer and Prance, 2002). At least eight major areas or endemism are recognized based on terrestrial vertebrates in Amazonia, but similar analysis using butterflies and vascular plants distributions support this pattern, indicating spatial congruence by taxa from different groups (Hall and Harvey, 2002; Prance, 1982). The major threats to these areas are: human population density, highways, cattle ranching, agriculture and drought, all of which increase burning, deforestation, habitat loss, and land degradation (Gascon et al., 2001; Laurance et al., 2002).

In the extreme eastern portion of the Amazon region is located one of the eight areas of endemism, the Belém Endemism Center (BEC) that incorporates the associated biomes east of the Tocantins River in the state of Pará and includes a greater portion in the state of Maranhão (Silva et al., 2005). With approximately $199,000 \mathrm{~km}^{2}$ total area, this area has the longest and highest levels of forest loss in Brazilian Amazon, retaining $<20 \%$ of its original primary forest cover and under some kind of protection (Almeida and Vieira, 2010), about $10 \%$ are conservation units, and 6\% are indigenous land (Silva et al., 2005). Recent evaluations of threatened species have shown that $61 \%$ of endangered birds in the Brazilian Amazon, occur on the BEC, several taxa have the highest level of local vulnerability in this area (Instituto Brasileiro do Meio Ambiente, 2014; Oren and Roma, 2011), and there is evidence of local extinction of $>40$ species in part of this area (Moura et al., 2014).

Among the insects, bees are the major group responsible for pollination of native and crop plants in the world (Klein et al., 2007; Michener, 2007). Orchid bees (Apidae, Euglossini) encompass around 250 endemic species of Neotropics (Nemésio and Rasmussen, 2011) and are the main pollinators of orchids and closely related with certain angiosperm families (Ackerman, 1989; Roubik, 1989; Roubik and Hanson, 2004). Some orchid bee species show sensitivity to environmental changes, suggesting that climatic regimes may influence the species distribution patterns of the group (Nemésio and Vasconcelos, 2013). Even the habitat loss and fragmentation (Brosi, 2009; Nemésio, 2013; Nemésio et al., 2016), and the multiple land use types have altered species composition and induced a decline on richness and abundance from disturbed to preserved habitats (Solar et al., 2015; Brito et al., 2017). Because of these particular characteristics, these bees have been highlighted as a key group of ecological disturbance indicator group.

Given the fast and historical land use changes in the BEC, recover information about species diversity of this unique area is fundamental to understanding the functioning of the systems and generate basis for studies addressing the effects of landscape changes on animal communities, which may be used as tools for restoration of degraded areas, and for identification of priority areas for conservation. Thus, in this paper we used orchid bee as a main group to provide data of abundance, richness and species composition from Belém Endemism Center, based on historical records of samples deposited in entomological collections. In addition to a species list occurring in the region, we provide an indication of the conservation status of the species based on data of frequency and dominance from each orchid bee species.

\section{Material and Methods}

\subsection{Data collection}

We have compiled euglossine bee information from surveys carried out in 27 of the 149 municipalities (sites) that are part of the Belém Endemism Center (BEC) (Figure 1). The specimens are deposited in the Museu Paraense Emílio Goeldi (MPEG), Embrapa Amazônia Oriental (Embrapa CPATU), Instituto Nacional de Pesquisas da Amazônia (INPA), Kansas University Bee Collection (KUBC), United States National Museum of Natural History-Smithsonian Institution (USNM), Coleção Entomológica do Instituto Oswaldo Cruz (CEIOC), Coleção de Abelhas da Faculdade de Filosofia, Ciências e Letras de Ribeirão Preto-Coleção Camargo (FFCL), and Departamento de Zoologia da Universidade Federal do Paraná-Coleção Pe. Jesus S. Moure (DZUP). These databases constitute records dating from 1917 to 2009 totalizing 92 years record. As this period, BEC had some municipalities today separated into two unities (i.e. part of Benevides is now the municipality of Santa Bárbara), the data on which the labels contained the locality "Santa Bárbara" we consider that the samples are from the new municipality. The cases of inaccuracy on the sample location, especially old records with reference only to the country or state, and specimens collected in islands were not included in our results. We also excluded the specimens with identification only to gender, since here we aim to approach the species found in this region. Taxonomic decisions were based on Moure's Bee Catalogue (Moure et al. 2012).

\subsection{Data analysis}

For each registered species was calculated occurrence frequency (FO) and dominance (D), following what has been proposed by Palma (1975) and adapted by Aguiar and Gaglianone (2008). For FO calculation, we adopted as samples the number of municipalities where the species was found $(\mathrm{FO}=$ (number of municipalities containing the species $\mathrm{x} /$ total number of municipalities) $\mathrm{x} 100$ ). For $\mathrm{FO}$ values $>50 \%$, the species was considered very frequent; if $50 \%>\mathrm{FO}>25 \%$ it was considered frequent species; and $\mathrm{FO}<25 \%$, it was considered less frequent. The dominance values $(\mathrm{D}=($ species abundance $\mathrm{x} /$ Total abundance $) \times 100)$ above $5 \%$ the species was named as dominant; if $5 \%>\mathrm{D}>2.5 \%$ it was considered incidental; and $\mathrm{D}<2.5 \%$ it was said 


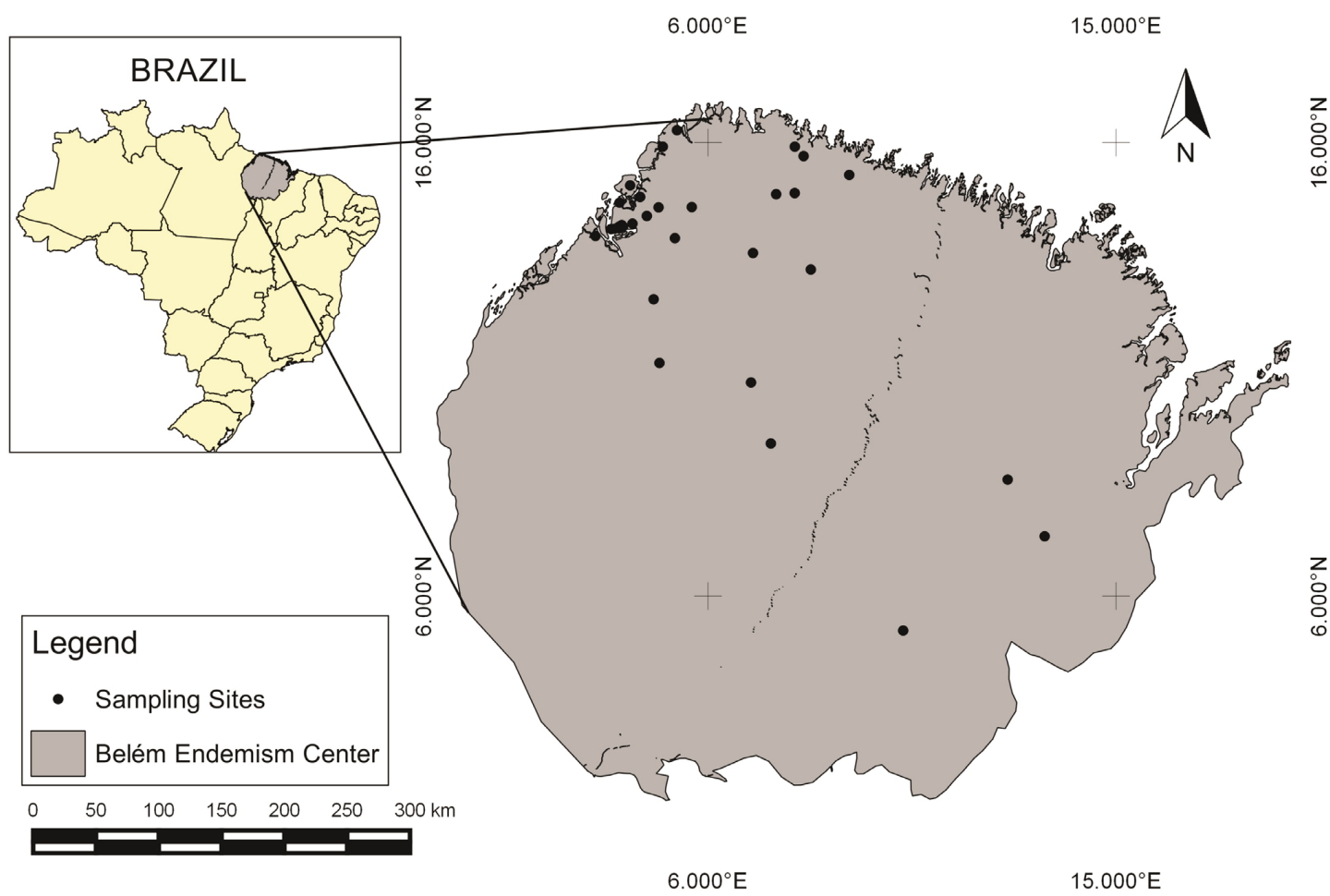

Figure 1. Sampling sites of orchid bees (Apidae: Euglossini) from surveys carried out from 1917 to 2009 in Belém Endemism Center, eastern Amazon, Brazil.

occasional. These indexes when grouped can be used to classify the species into three categories: common species, intermediate and rare species.

We calculated estimator of species richness based on first-order Jackknife on EstimateS Win9.10 software (Colwell, 2013), using the sites as samples, and built a curve of observed and estimated richness.

\section{Results}

During our research, we found 1,257 specimens of 56 species, belonging to the five genera of orchid bees (Table 1). In 92 years of collecting data in the Belém Endemism Center, approximately $43.20 \%$ of specimens were from Eulaema genus, followed by Euglossa (41.37\%), Eufriesea (7.80\%), Exaerete (6.36\%) and Aglae (1.27\%).

The most representative species were Eulaema cingulata (Fabricius, 1804) (16.31\% of total records), followed by E. meriana Olivier, 1789 (10.02\%) and E. nigrita Lepeletier, 1841 (8.27\%), all classified as common species. Moreover, Eufriesea convexa Friese, 1899; E. flaviventris Friese, 1899; E. laniventris Ducke, 1902; Euglossa aff. mixta Friese, 1899; E. bidentata Dressler, 1982; E. cognata Moure, 1970; E. ioprosopa Dressler, 1982; E. laevicincta Dressler, 1982; E. liopoda Dressler, 1982; E. polita Ducke, 1902; E. viridifrons Dressler, 1982; Eulaema tenuifasciata Friese, 1925 and Exaerete frontalis Guérin, 1844 showed low number of specimens, responding together of about $1 \%$, and are here classified as rare species (Table 1).
Regarding the sites that have been sampled since 1917, we found a high number of specimens and species concentrated in a few localities. Approximately $48 \%$ of all specimens deposited in the collections are samples from Belém city and its surroundings (47 species), followed by the municipalities of Benevides (38 species; $27.29 \%$ of total specimens) and Tomé-Açú (18 species; $15.19 \%$ of total specimens) (Figure 2). During the first 40 years of orchid bee records in BEC, there were few samples deposited in all collections. However, there was a significant increase of specimens from surveys in the $70 \mathrm{~s}$, but especially at the beginning of the current century, corresponding to about $50.27 \%$ of total records (Figure 3-A). Accumulation curve of species sampled in BEC is lower than estimated richness based on first-order Jackknife (Figure 3-B).

We checked the species distribution recorded in our research with information available on the literature for Neotropical region (Dressler, 1982a, b, c; Hinojosa-Díaz and Engel, 2014; Oliveira, 2006, 2007; Ramírez et al., 2002, 2015), Brazilian Amazon (Nemésio and Morato, 2004, 2006; Nemésio, 2005; Oliveira and Campos, 1995; Oliveira and Nemésio, 2003; Santos-Júnior et al., 2014; Storck-Tonon et al., 2009, 2011, 2013); Atlantic Forest and Cerrado (Nemésio, 2009, 2010, 2012b; Nemésio and Silveira, 2007, 2010; Nemésio and Faria-Junior, 2004; Oliveira-Junior et al., 2015; Silva, 2012); and current studies carried out on the states of Pará and Maranhão (Antonini et al., 2017; Brito et al., 2017; Brito and Rêgo, 
Table 1. Composition, number of specimens recorded, frequency of occurrence (FO), dominance (D) and category (CAT) of orchid bees from entomological collections, with occurrence in the municipalities of Belém Endemism Center, eastern Amazon, Brazil. CAT codes: Rare $=$ species classified as less frequent and occasional, Common $=$ species very frequent or frequent and dominant, and Inter = Intermediate, species classified as frequent and incidental, frequent and occasional, or frequent and incidental.

\begin{tabular}{|c|c|c|c|c|}
\hline Species & $\begin{array}{c}\text { Number of } \\
\text { records }\end{array}$ & FO & D & CAT \\
\hline Aglae caerulea Lepeletier \& Serville, 1825 & 16 & 14.81 & 1.27 & Rare \\
\hline Eufriesea auripes (Gribodo, 1882) & 2 & 3.70 & 0.16 & Rare \\
\hline Eufriesea concava (Friese, 1899) & 5 & 11.11 & 0.40 & Rare \\
\hline Eufriesea convexa (Friese, 1899) & 1 & 3.70 & 0.08 & Rare \\
\hline Eufriesea elegans (Lepeletier, 1841) & 11 & 18.52 & 0.88 & Rare \\
\hline Eufriesea fallax (Smith, 1854) & 2 & 7.41 & 0.16 & Rare \\
\hline Eufriesea flaviventris (Friese, 1899) & 1 & 3.70 & 0.08 & Rare \\
\hline Eufriesea laniventris (Ducke, 1902) & 1 & 3.70 & 0.08 & Rare \\
\hline Eufriesea mussitans (Fabricius, 1787) & 20 & 11.11 & 1.59 & Rare \\
\hline Eufriesea pulchra (Smith, 1854) & 34 & 11.11 & 2.70 & Inter \\
\hline Eufriesea purpurata (Mocsáry, 1896) & 4 & 11.11 & 0.32 & Rare \\
\hline Eufriesea surinamensis (Linnaeus, 1758) & 17 & 3.70 & 1.35 & Rare \\
\hline Euglossa (Euglossa) aff. mixta Friese, 1899 & 1 & 3.70 & 0.08 & Rare \\
\hline Euglossa (Euglossa) amazonica Dressler, 1982 & 52 & 11.11 & 4.14 & Inter \\
\hline Euglossa (Euglossa) bidentata Dressler, 1982 & 1 & 3.70 & 0.08 & Rare \\
\hline Euglossa (Euglossa) carolina Nemésio, 2009 & 5 & 3.70 & 0.40 & Rare \\
\hline Euglossa (Euglossa) chlorina Dressler, 1982 & 2 & 7.41 & 0.16 & Rare \\
\hline Euglossa (Euglossa) cognata Moure, 1970 & 1 & 3.70 & 0.08 & Rare \\
\hline Euglossa (Euglossa) cordata (Linnaeus, 1758) & 68 & 7.41 & 5.41 & Inter \\
\hline Euglossa (Euglossa) despecta Moure, 1968 & 3 & 7.41 & 0.24 & Rare \\
\hline Euglossa (Euglossa) gaianii Dressler, 1982 & 57 & 11.11 & 4.53 & Inter \\
\hline Euglossa (Euglossa) ioprosopa Dressler 1982 & 1 & 3.70 & 0.08 & Rare \\
\hline Euglossa (Euglossa) liopoda Dressler 1982 & 1 & 3.70 & 0.08 & Rare \\
\hline Euglossa (Euglossa) magnipes Dressler 1982 & 2 & 3.70 & 0.16 & Rare \\
\hline Euglossa (Euglossa) modestior Dressler 1982 & 41 & 7.41 & 3.26 & Inter \\
\hline Euglossa (Euglossa) mourei Dressler, 1982 & 2 & 3.70 & 0.16 & Rare \\
\hline Euglossa (Euglossa) securigera Dressler, 1982 & 5 & 11.11 & 0.40 & Rare \\
\hline Euglossa (Euglossa) variabilis Friese, 1899 & 3 & 7.41 & 0.24 & Rare \\
\hline Euglossa (Euglossella) decorata Smith, 1874 & 6 & 7.41 & 0.48 & Rare \\
\hline Euglossa (Euglossella) viridis (Perty, 1833) & 25 & 3.70 & 0.08 & Rare \\
\hline Euglossa (Euglossella) polita Ducke, 1902 & 1 & 14.81 & 1.99 & Rare \\
\hline Euglossa (Glossura) chalybeata Friese, 1925 & 13 & 11.11 & 1.03 & Rare \\
\hline Euglossa (Glossura) ignita Smith, 1874 & 76 & 18.52 & 6.05 & Inter \\
\hline Euglossa (Glossura) imperialis Cockerell, 1922 & 22 & 11.11 & 1.75 & Rare \\
\hline Euglossa (Glossura) orellana Roubik, 2004 & 35 & 11.11 & 2.78 & Inter \\
\hline Euglossa (Glossura) piliventris Guérin, 1844 & 23 & 18.52 & 1.83 & Rare \\
\hline Euglossa (Glossura) viridifrons Dressler 1982 & 1 & 3.70 & 0.08 & Rare \\
\hline Euglossa (Glossurella) augaspis Dressler 1982 & 5 & 7.41 & 0.40 & Rare \\
\hline Euglossa (Glossurella) laevicincta Dressler, 1982 & 1 & 3.70 & 0.08 & Rare \\
\hline Euglossa (Glossurella) parvula Dressler, 1982 & 4 & 7.41 & 0.32 & Rare \\
\hline Euglossa (Glossurella) prasina Dressler, 1982 & 2 & 3.70 & 0.16 & Rare \\
\hline Euglossa (Glossurella) stilbonota Dressler, 1982 & 5 & 7.41 & 0.40 & Rare \\
\hline Euglossa (Glossuropoda) intersecta Latreille, 1817 & 38 & 22.22 & 3.02 & Inter \\
\hline Euglossa sp. n. aff. mixta. Oliveira m.s. & 18 & 7.41 & 1.43 & Rare \\
\hline Eulaema (Apeulaema) cingulata (Fabricius, 1804) & 205 & 51.85 & 16.31 & Common \\
\hline Eulaema (Apeulaema) mocsaryi (Friese, 1899) & 5 & 14.81 & 0.40 & Rare \\
\hline
\end{tabular}


Table 1. Continued...

\begin{tabular}{lcccc}
\hline \multicolumn{1}{c}{ Species } & $\begin{array}{c}\text { Number of } \\
\text { records }\end{array}$ & FO & D & CAT \\
\hline Eulaema (Apeulaema) nigrita Lepeletier, 1841 & 104 & 44.44 & 8.27 & Common \\
Eulaema (Apeulaema) pseudocingulata Oliveira, 2006 & 74 & 18.52 & 5.89 & Inter \\
Eulaema (Eulaema) bombiformis (Packard, 1869) & 15 & 14.81 & 1.19 & Rare \\
Eulaema (Eulaema) meriana (Olivier, 1789) & 126 & 29.63 & 10.02 & Common \\
Eulaema (Eulaema) polyzona (Mocsáry, 1897) & 13 & 11.11 & 1.03 & Rare \\
Eulaema (Eulaema) tenuifasciata (Friese, 1925) & 1 & 3.70 & 0.08 & Rare \\
Exaerete dentata (Linnaeus, 1758) & 5 & 7.41 & 0.40 & Rare \\
Exaerete frontalis (Guérin, 1844) & 1 & 3.70 & 0.08 & Rare \\
Exaerete lepeletieri Oliveira \& Nemésio, 2003 & 10 & 14.81 & 0.80 & Rare \\
Exaerete smaragdina (Guérin, 1844) & 64 & 18.52 & 5.09 & Inter \\
\hline
\end{tabular}

A)

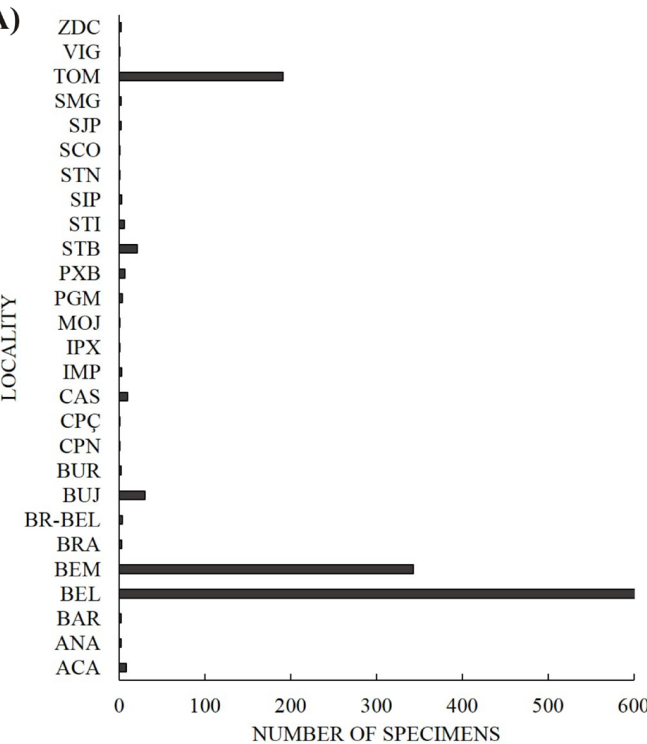

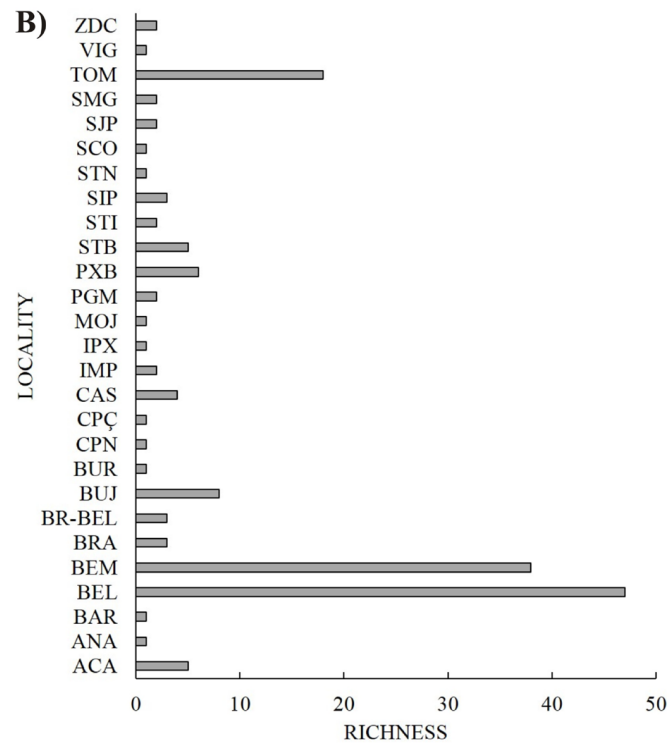

Figure 2. (A) Number of specimens and (B) species of orchid bees recorded in 27 localities from Belém Endemism Center, eastern Amazon, Brazil. Localities codes: $\mathrm{ACA}=\mathrm{Acará}, \mathrm{ANA}=\mathrm{Ananindeua}, \mathrm{BAR}=\mathrm{Barcarena}, \mathrm{BEL}=\mathrm{Belém}, \mathrm{BEM}=\mathrm{Benevides}$, $\mathrm{BRA}=$ Bragança, BR-BEL=BR Belém-Brasília, BUJ=Bujaru, BUR=Buriticupu, $\mathrm{CPN}=\mathrm{Capanema}, \mathrm{CPC}=\mathrm{Capitão}$ Poço, $\mathrm{CAS}=$ Castanhal, IMP=Imperatriz, IPX=Ipixuna, MOJ=Moju, $\mathrm{PGM}=$ Paragominas, $\mathrm{PXB}=$ Peixe Boi, STB=Santa Bárbara, STI=Santa Inês, SIP=Santa Isabel do Pará, STN=Santarém Novo, SCO=São Caetano de Odivelas, SJP=São João de Pirabas, $\mathrm{SMG}=$ São Miguel do Guamá, TOM=Tomé-Açu, VIG=Vigia, ZDC=Zé Doca.

2001; Maués et al., 2008; Rebêlo and Cabral, 1997; Silva and Rebêlo, 1999, 2002; Solar et al., 2016).

We found one species with new record for BEC. In Brazil, Euglossa prasina Dressler, 1982 is recognized as occurring on Amazon basin and Southwestern Amazon (Dressler, 1982b; Nemésio, 2009; Nemésio and Morato, 2004; Oliveira and Campos, 1995; Storck-Tonon et al., 2013), and there is only one recent record in the municipality of Oriximiná, Pará, located on Central Amazonia (Antonini et al., 2017).

\section{Discussion}

The results of this study suggest a high richness of orchid bees in the Belém Endemism Center and the occurrence of a high number of rare species, based on data from biological collections and whose specimens were collected in years prior to 2009 . Nevertheless, the number of species sampled in BEC is far from what is expected to be recorded, since the species accumulation curves never plateaued, indicating that the communities are under-sampled in the entire area. Moreover, the concentration of most records in few locations may have occurred both due to the proximity of these areas, especially Belém and Benevides (which are less than $30 \mathrm{~km}$ away from each other), but also because of the proximity of the sampled sites to cities, which promoted easy access to research institutions and their partners, increasing sampling efforts carried out in these areas.

The number of published studies showing the species composition of orchid bee fauna in the states of Pará and 
A)

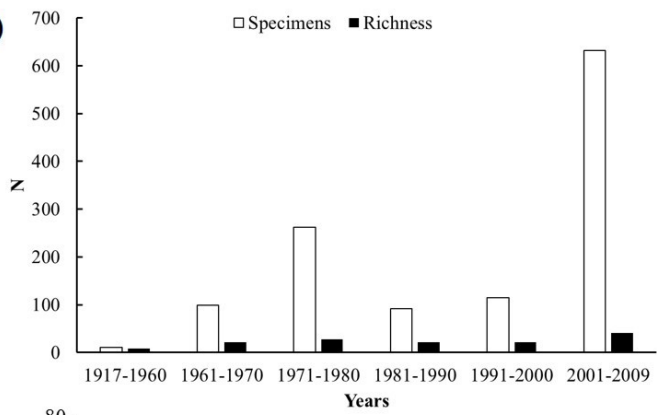

B)

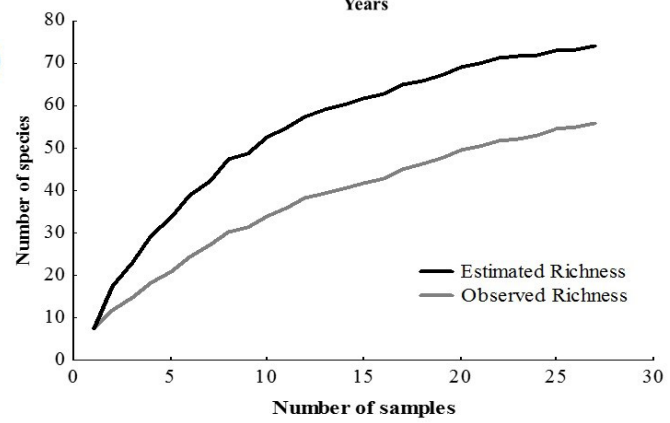

Figure 3. (A) Total number of specimens and species of orchid bees recorded in 92 years of sampling data, and (B) cumulative curves of estimated and observed species in the Belém Endemism Center, eastern Amazon, Brazil.

Maranhão is still less significant (Brito and Rêgo, 2001; Silva and Rebêlo, 1999) and most of them are small inventories carried out in very specific localities (Maués et al., 2012; Moura et al., 2011; Santos et al., 2011; Pereira et al., 2014; Taniguchi et al., 2012). Although recent studies have been taken on the state of Pará, addressing the effects of land use, isolation and climate changes on orchid bee assemblages, they are concentrated in the southeast and western of the state of Pará, outside of the BEC domain (Antonini et al., 2017; Brito et al., 2017; Solar et al., 2016), and ours is the first to addresses the rescue of historical records of these bees in the area.

Eulaema cingulata, E. meriana and E. nigrita are the species that stand out in inventories and monitoring samplings of the orchid bee fauna carried out in the Amazon (Nemésio, 2005; Storck-Tonon et al., 2013), and the latter one also appears in high abundance in other Brazilian forest areas, such as Atlantic Forest and Cerrado (Oliveira et al., 2015; Pires et al., 2013). Orchid bees are an important group of Neotropical pollinators and are particularly vulnerable to the effects of deforestation than other bee groups, with some species occurring only in continuous forest (Brosi, 2009; Becker et al., 1991; Powell and Powell, 1987), but most species appear to respond to specific and ephemeral local conditions (Tonhasca et al., 2002) and forest patch isolation (Storck-Tonon and Peres, 2017). Given the historical landscape change in BEC, some orchid bee species may have already suffered or being negatively affected. However, there is evidence that landscape features in Brazilian Cerrado did not affect, at least, E. nigrita occurrence, where even in pristine areas the vegetation is naturally opened when compared with pristine areas of Amazonian and Atlantic rainforests (Silva and Marco-Junior, 2014).

First surveys with scent baits were performed in Central America, in order to evaluate the bees attracted to pure compounds and to mixtures of compounds in 1968 (Dodson et al., 1969). Therefore, the increase of specimens in collections after the first 50 years is probably related with the use of new techniques of orchid bee surveys using chemical scent attractants, since those fragrances could be artificially synthesized. In addition, the growing interest in the effects of environmental factors, such as habitat fragmentation, on orchid bee assemblages, may have encouraged increasing research and sampling in the region from the 2000's (Martins et al., 2016; Moura et al., 2011; Taniguchi et al., 2012).

Although we have recorded a large number of species considered rare, there are some aspects that can affect these results in orchid bee communities. Differences in sampling effort, considering that surveys were concentrated in a few sites and the sporadic frequency of samplings (Silveira et al., 2011), the efficiency of sampling method, either by the use of few attractive substances and the collection method used (Nemésio and Morato, 2004; Nemésio, 2012a), or differences in the way these scents were handled and offered to the bees (Nemésio and Rasmussen, 2014), are all some of possible explanations to variations found on species richness and abundance in euglossine communities.

A recent study addressing digital and non-digital records of orchid bees in Brazilian Amazon, showed that in $>50 \%$ of collection places it is known the presence of just one orchid bee species, indicating that the majority of the locations sampled represent casual collections (Oliveira et al., 2017). The species Euglossa imperialis and Exaerete frontalis categorized in this work as rare species, are actually very common, being collected in most inventories carried out in Amazonia (e.g. Silva and Rebêlo, 1999; Oliveira and Campos, 1995). Thus, the status of "rare" attributed to them may be related to a low representativeness in the studied collections.

Our results show that, despite a long period of recordings of orchid bees at BEC, there is still a large gap of sites with no information about species composition, richness and occurrence of these bees in this area. The Amazon basin contains about 127 species of euglossine bees (Nemésio and Silveira, 2007), and in this study, was possible to record more than $40 \%$ of this species analyzing historical data in the BEC. Nevertheless, we emphasize the importance of distributing more sampling sites, especially in the state of Maranhão, given the rapid disappearance of natural vegetation and few conservation units in the state (Oliveira et al., 2017), but also in southwestern portion of the state of Pará. Additionally, is necessary to adopt standardized studies with orchid bees in future sampling in the region.

Contrary to what have been shown for Atlantic Forest in Brazil (Garraffoni et al., 2017; Nemésio and Santos-Junior, 
2014), we did not find endemic species of BEC. Pearson and Dressler (1985) suggested that orchid bees apparently were not affected by historical isolation and speciation events occurred on forest refuges during the Pleistocene. Thus, the group may not respond to these biogeographic entities in the Amazon, what means that many euglossine species range across extensive geographic areas. Even so, the list and the conservation status of species we presented in this study may be useful information in later works interested to compare the past and current orchid bee fauna, and, allied to data on bees' responses to land use changes occurred in BEC over the years, can fit as a basis for defining priority areas for conservation.

\section{Acknowledgements}

We thank CAPES - Coordenação de Aperfeiçoamento de Pessoal de Nível Superior (grant FAPAC 007/2014). We received financial support from Instituto Nacional de Ciência e Tecnologia - Biodiversidade e Uso da Terra na Amazônia (CNPq 574008/2008-0). We also thank Luiz Henrique Borges (Programa de Pós-Graduação em Ecologia - UFPA) for his readiness to draw up the study area map. MLO is scholarship of CNPq (process \#306100/2016-9).

\section{References}

ACKERMAN, J.D., 1989. Geographic and seasonal variation in fragrance choices and preferences of male euglossine bees. Biotropica, vol. 21, no. 4, pp. 340-347. http://dx.doi.org/10.2307/2388284.

AGUIAR, W.M. and GAGLIANONE, M.C., 2008. Comunidade de Abelhas Euglossina (Hymenoptera: Apidae) em Remanescentes de Mata Estacional Semidecidual sobre Tabuleiro no Estado do Rio de Janeiro. Neotropical Entomology, vol. 37, no. 2, pp. 118-125. http://dx.doi.org/10.1590/S1519-566X2008000200002. PMid:18506288.

ALMEIDA, A.S. and VIEIRA, I.C.G., 2010. Centro de endemismo Belém: status da vegetação remanescente e desafios para a conservação da biodiversidade e restauração ecológica. Revista de Estudos Universitários, vol. 36, no. 3, pp. 95-111.

ANTONINI, Y., MACHADO, C.B., GALETTI JUNIOR, P.M., OLIVEIRA, M., DIRZO, R. and FERNANDES, G.W., 2017. Patterns of orchid bee species diversity and turnover among forested plateaus of central Amazonia. PLoS One, vol. 12, no. 4, pp. e0175884. http://dx.doi.org/10.1371/journal.pone.0175884. PMid:28410432.

BECKER, P., MOURE, J.S. and PERALTA, F.J.A., 1991. More about euglossine bees in Amazonian forest fragments. Biotropica, vol. 23, no. 4, pp. 586-591. http://dx.doi.org/10.2307/2388396.

BRITO, C.M.S. and RÊGO, M.M.C., 2001. Community of male Euglossini Bees (Hymenoptera: Apidae) in a secondary forest, Alcântara, MA, Brazil. Brazilian Journal of Biology = Revista Brasileira de Biologia, vol. 61, no. 4, pp. 631-638. http://dx.doi. org/10.1590/S1519-69842001000400012. PMid:12071319.

BRITO, T.F., PHIFER, C.C., KNOWLTON, J.L., FISER, C.M., BECKER, N.M., BARROS, F.C., CONTRERA, F.A.L., MAUÉS, M.M., JUEN, L., MONTAG, L.F.A., WEBSTER, C.R., FLASPOHLER, D.J., SANTOS, M.P.D. and SILVA, D.P., 2017. Forest reserves and riparian corridors help maintain orchid bee (Hymenoptera: Euglossini) communities in oil palm plantations in Brazil. Apidologie, vol. 48, no. 5, pp. 575-587. http://dx.doi.org/10.1007/s13592-017-0500-z.

BROSI, B.J., 2009. The effects of forest fragmentation on euglossine bee communities (Hymenoptera: Apidae: Euglossini). Biological Conservation, vol. 142, no. 2, pp. 414-423. http:// dx.doi.org/10.1016/j.biocon.2008.11.003.

COLWELL, R.K., 2013. EstimateS: statistical estimation of species richness and shared species from samples. Version 9. Connecticut: UConn.

CRACRAFT, J. and PRUM, R.O., 1988. Patterns and processes of diversification: speciation and historical congruence in some Neotropical birds. Evolution; International Journal of Organic Evolution, vol. 42, no. 3, pp. 603-620. http://dx.doi. org/10.1111/j.1558-5646.1988.tb04164.x. PMid:28563998.

DODSON, C.H., DRESSLER, R.L., HILLS, G.H., ADAMS, R.M. and WILLIAMS, N.H., 1969. Biologically active compounds in orchid fragrances. Science, vol. 164, no. 3885, pp. 1243-1249. http://dx.doi.org/10.1126/science.164.3885.1243. PMid:17772561.

DRESSLER, R.L., 1982a. New species of Euglossa. II. (Hymenoptera: Apidae). Revista de Biología Tropical, vol. 30, no. 2, pp. 121-129.

DRESSLER, R.L., 1982b. New species of Euglossa. III. The bursigera species group (Hymenoptera: Apidae). Revista de Biología Tropical, vol. 30, no. 2, pp. 131-140.

DRESSLER, R.L., 1982c. New species of Euglossa. IV. The cordata and purpurea species group (Hymenoptera: Apidae). Revista de Biología Tropical, vol. 30, no. 2, pp. 141-150.

GARRAFFONI, A.R.S., MOURA, F.R. and LOURENÇO, A.P., 2017. Areas of endemism in the Atlantic Forest: quantitative biogeography insights from orchid bees (Apidae: Euglossini). Apidologie, vol. 48, no. 4, pp. 513-522. http://dx.doi.org/10.1007/ s13592-017-0494-6.

GASCON, C., BIERREGAARD JUNIOR, R.O., LAURANCE, W.F. and RANKIN-DEMERONA, J. 2001. Deforestation and forest fragmentation in the Amazon. In: R.O. BIERREGAARD, C. GASCON, T.E. LOVEJOY and R. MESQUITA, eds. Lessons from Amazonia: the ecology and conservation of a fragmented forest. Connecticut: Yale University Press, pp. 22-30.

HAFFER, J. and PRANCE, G.T., 2002. Impulsos climáticos da evolução na Amazônia durante o Cenozóico: sobre a teoria dos refúgios da diferenciação biótica. Estudos Avançados, vol. 16, no. 46, pp. 175-206. http://dx.doi.org/10.1590/S010340142002000300014

HALL, J.P.W. and HARVEY, D., 2002. The phylogeography of Amazonia revisited: new evidence from riodinid butterflies. Evolution; International Journal of Organic Evolution, vol. 56, no. 7, pp. 1489-1497. http://dx.doi.org/10.1111/j.0014-3820.2002. tb01460.x. PMid:12206248.

HINOJOSA-DÍAZ, I.A. and ENGEL, M., 2014. Revision of the orchid bee subgenus Euglossella (Hymenoptera: Apidae), Part II: The viridis and mandibularis species groups. Journal of Melittology, vol. 26, no. 36, pp. 1-108. http://dx.doi.org/10.17161/ jom.v0i36.4777.

INSTITUTO BRASILEIRO DO MEIO AMBIENTE - IBAMA. 2014 [viewed 17 May 2017]. Lista das espécies da fauna brasileira ameaçada de extinção [online]. Brasília: Ministério do Meio Ambiente. Available from: http://www.ibama.gov.br 
KLEIN, A.M., VAISSIÈRE, B.E., CANE, J.H., STEFFANDEWENTER, I., CUNNINGHAM, S.A., KREMEN, C. and TSCHARNTKE, T., 2007. Importance of pollinators in changing landscapes for world crops. Proceedings. Biological Sciences, vol. 274, no. 1608, pp. 303-313. http://dx.doi.org/10.1098/ rspb.2006.3721. PMid:17164193.

LAURANCE, W.F., ALBERNAZ, A.K.M., SCHROTH, G., FEARNSIDE, P.M., BERGEN, S., VENTICINQUE, E.M. and COSTA, C., 2002. Predictors of deforestation in the Brazilian Amazon. Journal of Biogeography, vol. 29, no. 5-6, pp. 737-748. http://dx.doi.org/10.1046/j.1365-2699.2002.00721.x.

MARTINS, D.C., ALBUQUERQUE, P.M.C., SILVA, F.S. and REBÊLO, J.M., 2016. First record of Aglae caerulea (Hymenoptera, Apidae, Euglossini) in Brazilian Cerrado east of the Amazon Region, Maranhão State, Brazil. Brazilian Journal of Biology = Revista Brasileira de Biologia, vol. 76, no. 2, pp. 554-556. http://dx.doi.org/10.1590/1519-6984.06415. PMid:26959953.

MAUÉS, M.M., MOURA, T.S.A., NASCIMENTO, I.M., MARTINS, M.B. and MOURÃO JUNIOR, M. 2012. Inventário estratificado da comunidade de machos de abelhas-das-orquídeas (Apidae, Euglossina) na Flona do Tapajós, Belterra, PA. In: Anais do $5^{\circ}$ Seminário Científico do PPBio Amazônia Oriental [online]. 08-12 Julho 2012, Macapá, Amapá, Brasil. Campinas: AINFO/ CNPTIA. Available from: http://ainfo.cnptia.embrapa.br/digital/ bitstream/item/103448/1/6764.pdf

MAUÉS, M.M., OLIVEIRA, P.E.A.M. and KANASHIRO, M., 2008. Pollination biology in Jacaranda copaia (Aubl.) D. Don. (Bignoniaceae) at the "Floresta Nacional do Tapajós", Central Amazon, Brazil. Revista Brasileira de Botanica. Brazilian Journal of Botany, vol. 31, no. 3, pp. 517-527. http://dx.doi.org/10.1590/ S0100-84042008000300015.

MICHENER, C.D. 2007. The bees of the world. 2nd ed. Baltimore: The Johns Hopkins University Press. 972 p.

MOURA, N.G., LEES, A.C., ALEIXO, A., BARLOW, J., DANTAS, S.M., FERREIRA, J., LIMA, M.F. and GARDNER, T.A., 2014. Two hundred years of local avian extinctions in Eastern Amazonia. Conservation Biology, vol. 28, no. 5, pp. 1271-1281. http://dx.doi.org/10.1111/cobi.12300. PMid:24779443.

MOURA, T.S.A., MAUÉS, M.M., SOUSA, J.T.A. and SANTOS, A.C.S. 2011. Biomonitoramento de abelhas euglossina (Apidae, Hymenoptera) em um SAF com castanheira-do-brasil (Bertholletia excelsa Bonpl., Lecythidaceae) em Tomé-Açu, Pará. In: Anais do $15^{\circ}$ Seminário de Iniciação Científica da Embrapa Amazônia Oriental. Embrapa Amazônia Oriental, 24-25 Agosto 2011, Belém, Pará, Brasil. Brasília: Embrapa. Available from: http:// ainfo.cnptia.embrapa.br/digital/bitstream/item/41283/1/Res-ExpSeminrioPIBIC2011-FINAL-JUL2011-TALYANNE-MOURA.pdf

MOURE, J.S., MELO, G.A.R. and FARIA JUNIOR, L.R.R. 2012 [viewed 17 May 2017]. Euglossini Latreille, 1802. In: J.S. MOURE, D. URBAN and G.R.A. MELO, orgs. Catalogue of Bees (Hymenoptera, Apoidea) in the Neotropical Region [online]. Available from: http://www.moure.cria.org.br/catalogue

NEMÉSIO, A. and FARIA-JUNIOR, L.R.R., 2004. First assessment of orchid bee fauna (Hymenoptera: Apidae: Apini: Euglossina) of Parque Estadual do Rio Preto, a cerrado area in southeastern Brazil. Lundiana, vol. 5, pp. 113-117.

NEMÉSIO, A. and MORATO, E.F., 2004. Euglossina (Hymenoptera: Apidae) of the Humaitá Reserve, Acre state, Brazilian Amazon, with comments on bait trap efficiency. Revista Tecnologia e Ambiente, vol. 10, pp. 71-80.
NEMÉSIO, A. and MORATO, E.F., 2006. The orchid-bee fauna (Hymenoptera: Apidae) of Acre state (northwestern Brazil) and a re-evaluation of euglossine bait-trapping. Lundiana, vol. 7, no. 1 , pp. 59-64.

NEMÉSIO, A. and RASMUSSEN, C., 2011. Nomenclatural issues in the orchid bees (Hymenoptera: Apidae: Euglossina) and an updated catalogue. Zootaxa, vol. 42, no. 1, pp. 1-42.

NEMÉSIO, A. and RASMUSSEN, C., 2014. Sampling a biodiversity hotspot: the orchid-bee fauna (Hymenoptera: Apidae) of Tarapoto, northeastern Peru, the richest and most diverse site of the Neotropics. Brazilian Journal of Biology $=$ Revista Brasileira de Biologia, vol. 74, no. 3, suppl. 1, pp. S33-S44. http://dx.doi. org/10.1590/1519-6984.20412. PMid:25627364.

NEMÉSIO, A. and SANTOS-JUNIOR, J., 2014. Is the "Centro de Endemismo Pernambuco" a biodiversity hotspot for orchid bees? Brazilian Journal of Biology $=$ Revista Brasileira de Biologia, vol. 74, no. 3, suppl. 1, pp. S78-S92. PMid:25627369.

NEMÉSIO, A. and SILVEIRA, F.A., 2007. Diversity and distribution of orchid bees (Hymenoptera: Apidae) with a revised checklist of species. Neotropical Entomology, vol. 36, no. 6, pp. 874-888. http://dx.doi.org/10.1590/S1519-566X2007000600008. PMid:18246261.

NEMÉSIO, A. and SILVEIRA, F.A., 2010. Forest Fragments with larger core areas better sustain diverse orchid bee faunas (Hymenoptera: Apidae: Euglossina). Neotropical Entomology, vol. 39, no. 4, pp. 555-561. http://dx.doi.org/10.1590/S1519566X2010000400014. PMid:20877991.

NEMÉSIO, A. and VASCONCELOS, H.L., 2013. Beta diversity of orchid bees in a tropical biodiversity hotspot. Biodiversity and Conservation, vol. 22, no. 8, pp. 1647-1661. http://dx.doi. org/10.1007/s10531-013-0500-x

NEMÉSIO, A., 2005. Orchid bees (Hymenoptera: Apidae) of Ilha de Maracá, Roraima, northern Brazil. Lundiana, vol. 6, no. 2, pp. 117-119.

NEMÉSIO, A., 2009. Orchid bees (Hymenoptera: Apidae) of the Brazilian Atlantic Forest. Zootaxa, vol. 2041, pp. 1-242.

NEMÉSIO, A., 2010. The orchid-bee fauna (Hymenoptera: Apidae) of a forest remnant in northeastern Brazil, with geographic records and an identification key to the known species of the Atlantic Forest of northeastern Brazil. Zootaxa, vol. 2656, pp. 55-66.

NEMÉSIO, A., 2012a. Methodological concerns and challenges in ecological studies with orchid bees (Hymenoptera: Apidae: Euglossina). Bioscience Journal, vol. 28, pp. 118-134.

NEMÉSIO, A., 2012b. The western limits of the "Hileia Baiana" for orchid bees, including seven new records for the state of Minas Gerais, eastern Brazil (Hymenoptera, Apidae, Euglossina). Spixiana, vol. 35, no. 1, pp. 109-116.

NEMÉSIO, A., 2013. Are orchid bees at risk? First comparative survey suggests declining populations of forest-dependent species. Brazilian Journal of Biology $=$ Revista Brasileira de Biologia, vol. 73, no. 2, pp. 367-374. http://dx.doi.org/10.1590/S151969842013000200017. PMid:23917564.

NEMÉSIO, A., SILVA, D.P., NABOUT, J.C. and VARELA, S., 2016. Effects of climate change and habitat loss on a forestdependent bee species in a tropical fragmented landscape. Insect Conservation and Diversity, vol. 9, no. 2, pp. 149-160. http:// dx.doi.org/10.1111/icad.12154. 
OLIVEIRA, M.L. and CAMPOS, L.A.O., 1995. Abundância, riqueza e diversidade de abelhas Euglossinae (Hymenoptera, Apidae) em florestas contínuas de terra firme na Amazônia Central, Brasil. Revista Brasileira de Zoologia, vol. 12, no. 3, pp. 547-556. http://dx.doi.org/10.1590/S0101-81751995000300009.

OLIVEIRA, M.L. and NEMÉSIO, A., 2003. Exaerete lepeletieri (Hymenoptera: Apidae: Apini: Euglossina): A new cleptoparasitic bee from Amazonia. Lundiana, vol. 4, no. 2, pp. 117-120.

OLIVEIRA, M.L., 2006. Três novas espécies de abelhas da Amazônia pertencentes ao gênero Eulaema (Hymenoptera: Apidae: Euglossini). Acta Amazonica, vol. 36, no. 1, pp. 121-128. http:// dx.doi.org/10.1590/S0044-59672006000100015.

OLIVEIRA, M.L., 2007. Catálogo comentado das espécies de abelhas do gênero Eulaema Lepeletier, 1841 (Hymenoptera: Apidae). Lundiana, vol. 8, no. 2, pp. 113-136.

OLIVEIRA, M.L., BROWN, J.C. and MOREIRA, M.P., 2017. Highway infrastructure, protected areas, and orchid bee distribution and conservation in the Brazilian Amazon. Journal of Environmental Protection, vol. 8, no. 8, pp. 923-939. http:// dx.doi.org/10.4236/jep.2017.88058.

OLIVEIRA, R., PINTO, C.E. and SCHLINDWEIN, C., 2015. Two common species dominate the species-rich Euglossine bee fauna of an Atlantic Rainforest remnant in Pernambuco, Brazil. Brazilian Journal of Biology = Revista Brasileira de Biologia, vol. 75, no. 4, suppl. 1, pp. S1-S8. http://dx.doi.org/10.1590/15196984.18513. PMid:26602351.

OLIVEIRA-JUNIOR, J.M.B., ALMEIDA, S.M., RODRIGUES, L., SILVÉRIO JÚNIOR, A.J. and ANJOS-SILVA, E.J., 2015. Orchid Bees (Apidae: Euglossini) in a forest fragment in the Ecotone Cerrado-Amazonian Forest, Brazil. Acta Biologica Colombiana, vol. 20, no. 3, pp. 67-78. http://dx.doi.org/10.15446/ abc.v20n3.41122.

OREN, D.C. and ROMA, J.C. 2011 [viewed 17 May 2017]. Composição e vulnerabilidade da avifauna da Amazônia Maranhense, Brasil. In: M.B. Martins and T.G. Oliveira, eds. Amazônia Maranhense-diversidade e conservação [online]. Belém: Museu Paraense Emílio Goeldi, pp. 221-248. Available from: https://issuu.com/museu-goeldi/docs/amazonia_maranhense/15

PALMA, S.G. 1975. Contribuición al studio de los Sifonoforos encontrados frente a la costa de Valparaiso: aspectos ecológicos. In: Memorias del Segundo Simposio Latinoamericano de Oceanografia Biológica, 24-28 Noviembre 1975, Cumaná, Venezuela. Venezuela: University de Oriente. pp. 119-133.

PEARSON, D.L. and DRESSLER, R.L., 1985. Two-year study of male orchid bee (Hymenoptera: Apidae: Euglossini) attraction to chemical baits in lowland south-eastern Perú. Journal of Tropical Ecology, vol. 1, no. 1, pp. 37-54. http://dx.doi.org/10.1017/ S0266467400000067.

PEREIRA, S.V.S., COSTA, T.S.M. and MAUÉS, M.M. 2014 [viewed 17 May 2017]. Abelhas Euglossina (Apidae, Hymenoptera) coletadas em armadilhas aromáticas em plantio de castanheirado-brasil (Bertholletia excelsa Bonpl.) em Tomé-Açu/PA. In: Anais do $20^{\circ}$ Congresso Brasileiro de Apicultura e $6^{\circ}$ Congresso Brasileiro de Meliponicultura, 5-8 Novembro 2014, Belém, Pará, Brasil. Brasília: Embrapa. Available from: http://ainfo.cnptia. embrapa.br/digital/bitstream/item/118864/1/Conbrapi-p33.pdf

PIRES, E.P., MORGADO, L.N., SOUZA, B., CARVALHO, C.F. and NEMÉSIO, A., 2013. Community of orchid bees (Hymenoptera: Apidae) in transitional vegetation between Cerrado and Atlantic Forest in southeastern Brazil. Brazilian Journal of
Biology $=$ Revista Brasileira de Biologia, vol. 73, no. 3, pp. 507-513. http://dx.doi.org/10.1590/S1519-69842013000300007. PMid:24212690.

POWELL, A.H. and POWELL, G.V.N., 1987. Population dynamics of male Euglossine bees in Amazonian forest fragments. Biotropica, vol. 19, no. 2, pp. 176-179. http://dx.doi.org/10.2307/2388742.

PRANCE, G.T. 1982. Forest refuges: evidence from woody angiosperms. In: G.T. PRANCE, ed. Biological diversification in the tropics. New York: Columbia University Press, pp. 137-158.

RAMÍREZ, S., DRESSLER, R.L. and OSPINA, M., 2002. Abejas euglosinas (Hymenoptera: Apidae) de la Región Neotropical: Listado de especies con notas sobre su biología. Biota Colombiana, vol. 3 , no. 1, pp. 7-118.

RAMÍREZ, S.R., HERNÁNDEZ, C., LINK, A. and LÓPEZURIBE, M.M., 2015. Seasonal cycles, phylogenetic assembly, and functional diversity of orchid bee communities. Ecology and Evolution, vol. 5, no. 9, pp. 1896-1907. http://dx.doi.org/10.1002/ ece3.1466. PMid:26140205.

REBÊLO, J.M.M. and CABRAL, A.J.M., 1997. Abelhas Euglossine de Barreirinhas, zona do litoral da baixada oriental maranhense. Acta Amazonica, vol. 27, no. 2, pp. 145-152. http:// dx.doi.org/10.1590/1809-43921997272152.

ROUBIK, D.W. 1989. Ecology and natural history of tropical bees. Cambridge: Cambridge University Press. 514 p. http:// dx.doi.org/10.1017/CBO9780511574641.

ROUBIK, D.W. and HANSON, P.E. 2004. Orchid bees of tropical America: biology and field guide. 1st ed. San José: INBio. 352 p.

SANTOS, T.F., MAUÉS, M.M., FIGUEIREDO, D.M. and MOURA, T.S.A. 2011. Biomonitoramento de abelhas da subtribo Euglossina (Hymenoptera: Apoidea) em um plantio de castanheira-do-brasil (Bertholletia excelsa Bonpl., Lecythidaceae) em Belém, Pará. In: Anais do $15^{\circ}$ Seminário de Iniciação Científica da Embrapa Amazônia Oriental [online]. 24-25 Agosto 2011, Belém, Pará, Brasil. Brasília: Embrapa. Available from: http:// ainfo.cnptia.embrapa.br/digital/bitstream/item/41350/1/ResumoPibic-2011-CORRIGIDO.pdf

SANTOS-JÚNIOR, J.E., FERRARI, R.R. and NEMÉSIO, A., 2014. The orchid-bee fauna (Hymenoptera: Apidae) of a forest remnant in the southern portion of the Brazilian Amazon. Brazilian Journal of Biology $=$ Revista Brasileira de Biologia, vol. 74, no. 3, suppl. 1, pp. S184-S190. http://dx.doi.org/10.1590/15196984.25712. PMid:25627384

SILVA, D.P. and MARCO JUNIOR, P., 2014. No Evidence of Habitat Loss Affecting the Orchid Bees Eulaema nigrita Lepeletier and Eufriesea auriceps Friese (Apidae: Euglossini) in the Brazilian Cerrado Savanna. Neotropical Entomology, vol. 43, no. 6, pp. 509-518. http://dx.doi.org/10.1007/s13744-014-0244-7. PMid:27194058.

SILVA, F.S. and REBÊLO, J.M.M., 1999. Euglossine bees (Hymenoptera: Apidae) of Buriticupu, Amazonia of Maranhão, Brazil. Acta Amazonica, vol. 29, no. 4, pp. 587-599. http://dx.doi. org/10.1590/1809-43921999294599.

SILVA, F.S. and REBÊLO, J.M.M., 2002. Population dynamics of Euglossinae bees (Hymenoptera, Apidae) in an early secondgrowth forest of Cajual Island, in the State of Maranhão, Brazil. Brazilian Journal of Biology $=$ Revista Brasileira de Biologia, vol. 62 , no. 1, pp. 15-23. http://dx.doi.org/10.1590/S151969842002000100003. PMid:12185914. 
SILVA, F.S., 2012. Orchid bee (Hymenoptera: Apidae) community from a gallery forest in the Brazilian Cerrado. Revista de Biología Tropical, vol. 60, no. 2, pp. 625-633. http://dx.doi.org/10.15517/ rbt.v60i2.3949. PMid:23894934.

SILVA, J.M.C., RYLANDS, A.B. and FONSECA, G.A.B., 2005. The Fate of the Amazonian Areas of Endemism. Conservation Biology, vol. 19, no. 3, pp. 689-694. http://dx.doi.org/10.1111/ j.1523-1739.2005.00705.x.

SILVEIRA, G.C., NASCIMENTO, A.M., SOFIA, S.H. and AUGUSTO, S.C., 2011. Diversity of the euglossine bee community (Hymenoptera, Apidae) of an Atlantic Forest remnant in southeastern Brazil. Revista Brasileira de Entomologia, vol. 55, no. 1, pp. 109-115. http://dx.doi.org/10.1590/S0085-56262011000100017.

SOLAR, R.R., BARLOW, J., FERREIRA, J., BERENGUER, E., LEES, A.C., THOMSON, J.R., LOUZADA, J., MAUÉS, M., MOURA, N.G., OLIVEIRA, V.H., CHAUL, J.C., SCHOEREDER, J.H., VIEIRA, I.C., MAC NALLY, R. and GARDNER, T.A., 2015. How pervasive is biotic homogenization in human-modified tropical forest landscapes? Ecology Letters, vol. 18, no. 10, pp. 1108-1118. http://dx.doi.org/10.1111/ele.12494. PMid:26299405.

SOLAR, R.R.C., CHAUL, J.C.M., MAUÉS, M. and SCHOEREDER, J.H., 2016. A quantitative baseline of ants and orchid bees in human-modified Amazonian landscapes in Paragominas, Pará, Brazil. Sociobiology, vol. 63, no. 3, pp. 925-940. http://dx.doi. org/10.13102/sociobiology.v63i3.1052.

STORCK-TONON, D. and PERES, C.A., 2017. Forest patch isolation drives local extinctions of Amazonian orchid bees in a 26 years old archipelago. Biological Conservation, vol. 214, pp. 270-277. http://dx.doi.org/10.1016/j.biocon.2017.07.018

STORCK-TONON, D., MORATO, E.F. and OLIVEIRA, M.L., 2009. Fauna de Euglossina (Hymenoptera: Apidae) da Amazônia Sul-Ocidental, Acre, Brasil. Acta Amazonica, vol. 39, no. 3, pp. 693-706. http://dx.doi.org/10.1590/S0044-59672009000300026.

STORCK-TONON, D., MORATO, E.F., MELO, A.W.F. and OLIVEIRA, M.L., 2013. Orchid bees of forest fragments in Southwestern Amazonia. Biota Neotropica, vol. 13, no. 1, pp. 133-141. http://dx.doi.org/10.1590/S1676-06032013000100015.

STORCK-TONON, D., SILVA, M.V. and MORATO, E.F., 2011. Checklist of orchid bees (Hymenoptera: Apidae) of "Lago do Silêncio" area, Boca do Acre, Amazonas, Brazil. Check List, vol. 7, no. 5, pp. 648-651. http://dx.doi.org/10.15560/7.5.648.

TANIGUCHI, T., MAUÉS, M.M. and MOURA, T.S.A. 2012 [viewed 17 May 2017]. Riqueza de espécies de abelhas euglossina (Hymenoptera, Apidae) em dois fragmentos florestais inseridos no arco do desmatamento amazônico, Estado do Pará. In: Anais do $16^{\circ}$ Seminário de Iniciação Científica da Embrapa. Embrapa Amazônia Oriental [online]. 16-17 Agosto 2012, Belém, Pará, Brasil. Brasília: Embrapa. Available from: http://ainfo.cnptia. embrapa.br/digital/bitstream/item/76571/1/Mariana-Taniguchi.pdf

TONHASCA, A., BLACKMER, J.L. and ALBUQUERQUE, G.S., 2002. Abundance and diversity of Euglossine Bees in the fragmented landscape of the Brazilian Atlantic Forest. Biotropica, vol. 34, no. 3, pp. 416-422. http://dx.doi.org/10.1111/j.1744-7429.2002. tb00555.x. 